For The Sake of Argument

No one has directly requested my comment on the intra-executive committee debate published at length in the June 1965 Chronicle, but I detect an oblique invitation in the Crossley letter of March 1. In fact, the wording almost requires a reply from either Bill Clark or myself, since the members of the Resolutions Committee who had the responsibility to place the motion before the meeting rather than the members present, who really produced the final lamented result, are apparently being called to account.

I suppose the most direct way into the argument is by a letter to the editor. In the hope that it may help the situation I offer the following comments.

First I feel that someone should convey the picture of the resolutions debate to the readers who were unfortunate enough to miss that session late the last day of the meeting after everything else had been dealt with and everyone was anxious to leave. It was a largely empty room; the Chairman was trying to meet a closing deadline (with the Hotel staff noisily banging furniture about, hinting loudly that we had overstayed our welcome); the Vice-President at one point felt compelled to remind the President that as Chairman he really should not be so outspoken about a motion before the meeting; a member of the institute was convinced, in the light of the discussion, that the Resolutions Committee should not have messed his resolution about so much, and an outspoken parks and wilderness proponent found 1(a) and 1(b) totally unacceptable and hastily presented 2(a) and 2(b) as an amendment which was merely tacked on; everybody then heaved a sigh of relief because that seemed to make all the debaters happy and we could now go and get organized to socialize.

Secondly, a word about procedure: I said so then, as Chairman of the Resolutions Committee, and I repeat now, that the only resolutions which should be accepted for presentation are those which had previously been circulated and were available for careful consideration before the meeting, preferably at the Section level.

None of the resolutions we presented were written before the meeting began. The Committee met Tuesday noon and attempted to polish up the notes given them by the originators of the resolutions. Rightly or wrongly the wording was changed to what we thought the meeting could accept. But the last item on the business agenda is no place for a debate about a resolution which can reflect so significantly on the CIF with the wide circulation it has been given to various Ministers of the Crown responsible for Parks administration, and through the continuing debate in the pages of the Chronicle.

Surely the Lakehead meeting will profit by this experience and provide time for a reasonable discussion if indeed there are any resolutions presented.

My next comment deals not with procedure, but with the resolution itself. On careful re-reading, I cannot accept the view that 1 (b) suggests the CIF "covets another man's timber for the purpose of manufacture" to use Des Crossley's phrase. In the resolution we were merely asking the Parks Administrators in jurisdictions where this is not now standard practice, to recognize within the larger parks, those areas which should be set aside for single 
purpose recreational or scientific use, and also those areas in which other uses would not conflict with the primary use of the park.

The resolution sought recognition of the wisdom of managing parks for additional purposes compatible with recreation and thereby achieving a healthier forest for recreation and at the same time harvesting a valuable crop.

In areas where aesthetics would be impaired by conventional logging, less obvious methods could be employed, but all this falls within the limits of the decision we ask the Parks Administrator to make. He need only say that a stand or an area could not be cut without impairing the primary use, but at least he would have considered the possibility and would not have been limited by a blanket "no-cut" policy.

I would endorse Des Crossley's suggestion of March 1, 1965, that the Policy Committee should deal with this matter. If the forestry profession in Canada feels obliged to have an opinion concerning Parks policy, it should be a carefully drafted and membership-approved statement, not a hastily amended resolution passed at an Annual Meeting by a handful of members.

\section{WALTER GILES,}

CHAIRMAN, RESOLUTIONS COMMITTEE 1964 ANNUAL MEETING

William STANLEy HePher

Stan Hepher, Manager of Timber and Lands, Rayonier Canada Ltd., died suddenly on July 27, 1965 in Lions Gate Hospital, North Vancouver, B.C. at the age of 59 years.

Stan was born in Boswell near Creston, B.C. and received high school education in Nelson, B.C., then graduated from the University of Idaho, with the degree of B.S.F., in 1930.

He joined the B.C. Forest Service following graduation and held field and office appointments in the Vancouver Forest District culminating in a Victoria headquarters assignment as Assistant Forester, $2 \mathrm{i} / \mathrm{c}$ Management Division.

Stan left the Service to join Salmon River Logging Co. Ltd. as Chief Forester at Kelsey Bay, B.C. and later joined Alaska Pine Co. Ltd. precursor of the present Rayonier Company. He rose steadily in his profession, readily assuming many committee appointments, notably the Insect Control Committee of the B.C. Loggers Association (during a serious spruce budworm epidemic in coastal forests) and the Tree Farm Foresters' Committee, both of which he had chaired.

He was an active member of the C.I.F., in both Vancouver Island and Vancouver Sections, being involved in numerous committees. He was one of the earlier members of the Association of B.C. Foresters (B.C.R.F. No. 36), was a member of Council in 1964 and took an active part in Association affairs for many years.

He was also Past President of the North Vancouver Lions Club and was active in many community activities involving youth programs.

Stan's quiet and kindly nature, combined with an outstanding ability to get 